\title{
Effects of cowpea cultivars and neem oil on attractiveness, feeding, and development of Spodoptera eridania (Cramer) (Lepidoptera: Noctuidae)
}

\author{
Efectos de cultivos de frijol caupí y aceite de nim en la atracción, \\ alimentación y desarrollo de Spodoptera eridania \\ (Cramer) (Lepidoptera: Noctuidae)
}

\author{
Nara Elisa Lobato Rodrigues ${ }^{1}$, Anderson Gonçalves da Silva ${ }^{*}$, \\ Bruno Henrique Sardinha de Souza ${ }^{1}$, Eduardo Neves Costa ${ }^{1}$, \\ Zulene Antônio Ribeiro ${ }^{1}$, Arlindo Leal Boiça Júnior ${ }^{1}$
}

\begin{abstract}
The southern armyworm Spodoptera eridania is a polyphagous species that can feed on cowpea plants. Although there is some knowledge about the resistance of cowpea cultivars, little is known on the effects of neem oil to control pest insects of cowpea in Brazil. This study aimed to evaluate the effects of cowpea cultivars combined with neem oil on attractiveness, feeding, and development of Spodoptera eridania (Cramer). The experiment was carried out under environmentally controlled conditions, and set up in a $6 \times 3$ factorial arrangement using six cowpea cultivars and two doses of neem oil plus the control (deionized water). Free-choice and no-choice feeding preference assays were performed to assess treatment attractiveness to the larvae and leaf consumption. Duration and survival of larvae, pre-pupae, and pupae, weights of larvae and pupae, longevity of adults, sex ratio, duration of larva-to-adult period, and larval mortality after 3, 6, 12, and 24 days were recorded. Cultivars BRS Urubuquara and BR17 Gurgueia were the least consumed in the free-choice test. Neem oil at 0.35 and $0.7 \%$ reduced leaf consumption. Cultivars BRS Novaera and BR17 Gurgueia showed to be the least suitable for S. eridania development. Neem oil at both doses affected S. eridania development. Cultivars BR7 Gurgueia and BRS Novaera were moderately resistant; BR3 Tracuateua, susceptible; and Sempre Verde, Milênio, and BRS Urubuquara were highly susceptible to $S$. eridania.
\end{abstract}

Key words: Vigna unguiculata, Azadirachta indica, southern armyworm, host plant resistance, natural product.

\section{RESUMEN}

Spodoptera eridania es una especie polífaga, cuya oruga puede alimentarse de plantas de caupí. Aunque hay algunos conocimientos sobre la resistencia de cultivares de caupí, se conoce poco sobre los efectos de aceite de nim para controlar insectos plaga de caupí, en Brasil. Esta investigación tuvo como objetivo evaluar los efectos de cultivares de caupí asociados con aceite de nim sobre la atracción, alimentación, y desarrollo de Spodoptera eridania (Cramer). El experimento se llevó a cabo bajo condiciones ambientales controladas, en un diseño factorial $6 \times 3$, evaluando seis cultivares de caupí y dos dosis de aceite de nim, además del tratamiento testigo (agua desionizada). Se realizaron pruebas de no preferencia para alimentación con y sin opción de escoger para evaluar la atracción de los tratamientos a las larvas y el consumo de las hojas. Se registró la duración y supervivencia de larvas, prepupas y pupas, pesos de larvas y pupas, longevidad de los adultos, proporción sexual, duración del período de larva a adulto, y mortalidad larval después de 3, 6, 12, y 24 días. Los cultivares BRS Urubuquara y BR17 Gurgueia fueron los menos consumidos en la prueba de libre elección. El consumo de hojas fue reducido cuando utilizó aceite de nim a 0,35 y 0,7\%. Los cultivares BRS Novaera y BR17 Gurgueia mostraron ser los menos adecuados para el desarrollo de S. eridania. Aceite de nim en ambas dosis afectó el desarrollo de S. eridania. Los cultivares BR7 Gurgueia y BRS Novaera fueron moderadamente resistentes; BR3 Tracuateua, susceptible; y Sempre Verde, Milênio, y BRS Urubuquara fueron altamente susceptibles a S. eridania.

Palabras clave: Vigna unguiculata, Azadirachta indica, resistencia de plantas a insectos, productos naturales.

\footnotetext{
$1 \quad$ Faculdade de Ciências Agrárias e Veterinárias - FCAV/UNESP, Departamento de Fitossanidade, Laboratório de Resistência de Plantas a Insetos, 14884-900, Jaboticabal, SP, Brazil.

* Corresponding author: anderson.silva@ufra.edu.br
}

Fecha de Recepción: 26 Abril, 2013.

Fecha de Aceptación: 6 Julio, 2015. 


\section{Introduction}

The southern armyworm Spodoptera eridania (Cramer, 1782) (Lepidoptera: Noctuidae) is a polyphagous species that can feed on plants of several crops such as maize, sorghum, vegetables, tomato, cotton, weeds, common beans, soybeans, and cowpea (Capinera, 2005; Souza et al., 2014a). The attack caused by S. eridania on cowpea plants, Vigna unguiculata (L.) Walp, may be significant. The larvae can cause complete destruction of the leaflets, reducing the plant photosynthetic area, and hence the yield of the plants (Pereira et al., 2009).

In Integrated Pest Management (IPM) systems, host plant resistance is employed as an additional tactic for pest control. Plants possessing high levels of resistance can reduce populations of phytophagous insects below economic thresholds, have cumulative and persistent effects, do not cause imbalances on the environment, do not require previous knowledge by the grower, and are compatible with other control methods (Lara, 1991; Boiça Júnior et al., 2011).

Given the need to adopt less harmful pest control tactics, extracts from some plants also have been studied as an alternative to the use of synthetic insecticides. The characteristics of botanical insecticides such as low toxicity and persistence make them produce less environmental impact (Costa; Santos; Boiça Júnior, 2004). Among the botanical insecticides, compounds extracted from neem, Azadirachta indica A. Juss. (Meliaceae), have shown activity against various lepidopteran pests; they can cause alterations in the development of insects, oviposition and feeding inhibition, reduction of growth and chitin biosynthesis, inhibition of ecdysis, morphological abnormalities, repellence, and mortality (Brunheroto \& Vendramim, 2001; Martinez \& Van Emden, 2001). Other characteristics of neem-based products favorable to its utilization in organic agriculture include rapid degradation, absence of risk of water and soil pollution, they are non-toxic to soil microflora, do not affect dehydrogenases, and do not influence negatively mineralization of soil nitrogen (Martinez, 2002). For many species of the genus Spodoptera, the insecticidal effects of neem also extends to the last larval instar depending on the product formulation and dose applied (Prabhaker et al., 1986; Liburd; Funderburk; Olson, 2000; Aggarwal; Holaschke; Basedow, 2006). Thus, neem extracts are worth to be tested for $S$. eridania control.
The cowpea crop is grown in the north and northeast regions of Brazil; it is strategic to familybased agriculture (Freire Filho et al., 2009). Small farms in these regions have potential for producing food following an organic-agriculture model. This is a conservationist production system of natural resources (IFOAM, 2007), with economic production of high-quality food and free of toxic residuals (Santos \& Santos, 2008). In this sense, cultivation of resistant cowpea cultivars isolated or combined with botanical insecticides are in agreement with sustainable agricultural systems, and may give satisfactory results for the cowpea growers of north and northeast regions of Brazil.

Although there is some knowledge about the levels of resistance of cowpea cultivars (Lima et al., 2002; Rodrigues; Boiça Júnior; Farias, 2012; Souza et al., 2012; Carvalho; Lima; Alves, 2011), little is known on the effects of neem oil to control pest insects of cowpea in Brazil. Knowledge on the efficacy of neem oil for pest control can be beneficial to sustainable agricultural systems since neem-based insecticides are less toxic than the plant extracts commonly used in organic agriculture, such as tobacco, Nicotiana tabacum L. (Solanaceae) and timbo, Derris spp. (Fabaceae). Thus, this study was designed to evaluate the effects of doses of neem oil applied on cowpea cultivars on attractiveness, feeding, and development of $S$. eridania.

\section{Materials and Methods}

\section{Location and laboratory conditions}

The experiment was carried out at the Faculdade de Ciências Agrárias e Veterinárias - FCAV/UNESP, Departamento de Fitossanidade, Laboratório de Resistência de Plantas a Insetos, Jaboticabal, state of São Paulo, Brazil, under controlled conditions of temperature $\left(25 \pm 1^{\circ} \mathrm{C}\right)$, relative humidity $(60 \pm$ $10 \%)$, and photophase (12 h).

\section{Treatments}

Treatments consisted of six cowpea cultivars, namely BR17 Gurgueia, BR3 Tracuateua, BRS Novaera, Sempre Verde, BRS Milênio and BRS Urubuquara, which were treated with two doses of neem oil, 0.35 and $0.7 \%$, at the concentration of $353 \mathrm{mg}$ azadirachtin $\mathrm{A} \mathrm{kg}^{-1}$, in addition to a control (deionized water), totaling 18 treatments. 


\section{Maintenance of cowpea plants and insects}

Plants of the cowpea cultivars were cultivated in 5-L plastic pots filled with soil, sand, and manure at 2:1:1 ratio, and placed in a greenhouse. Larvae of S. eridania used in the experiment were from a stock colony maintained in the laboratory and fed on artificial medium (Greene; Leppla; Dickerson, 1976).

\section{Feeding preference assays}

Free-choice and no-choice feeding preference assays were performed. In both, leaves were collected from plants of the cowpea cultivars in the greenhouse, and 2.5 -cm-diameter leaf discs were prepared using a punch. Thereafter, the leaf discs were immersed for one minute in plastic containers containing neem oil at the doses of 0.35 and $0.7 \%(353 \mathrm{mg}$ azadirachtin $\mathrm{A} \mathrm{kg}^{-1}$ of the oil). Deionized water was used as the control treatment. The experiment was set up in a $6 \times 3$ factorial scheme, represented by the cowpea cultivars by the neem oil doses plus control, respectively.

In the free-choice tests, leaf discs were placed equidistantly in glass plates ( $26.4 \mathrm{~cm}$ diameter by 5.8 $\mathrm{cm}$ height), lined with filter paper lightly moistened with distilled water and covered with glass square plates with $35 \mathrm{~cm}$ each side. Next, one fourth-instar larva of S. eridania per treatment was released in the center of the plate, totaling 18 larvae released per replicate. For the no-choice assay, 9-cm-diameter acrylic Petri dishes were lined with filter paper lightly moistened with distilled water, and one fourth-instar larva was released per replicate. In both assays, treatment attractiveness to the larvae was assessed at 1, 3, 5, 10, 15, 30, 60, 120, and 360 min after larvae release. In addition, the leaf area consumed was measured at the end of the assays using an electronic leaf area meter (LI-COR 3100, LI-COR, Lincoln, NE, USA). Randomized block design and complete randomized design were used in the free-choice and no-choice assays, respectively, with five replications each.

\section{Evaluation of biological aspects}

The evaluation of the biological parameters of S. eridania was conducted in 9-cm-diameter Petri dishes lined with filter paper lightly moistened with distilled water. One neonate larvae was transferred per Petri dish, which consisted of a replicate. Leaves were detached from the cowpea plants and immersed for one minute into the neem oil at the respective doses.

Observations were performed daily, and the following biological parameters were recorded from S. eridania: duration and survival of larvae, pre-pupae, and pupae; weights of 15-day-old larvae and 24-hour-old pupae; longevity of adults; sex ratio; duration of larva-to-adult period, and mortality of larvae after 3, 6, 12, and 24 days. A complete randomized design was used in this assay, with 25 replications.

For statistical analysis, the data obtained were submitted to the analysis of variance (ANOVA) by F test and means were compared by Tukey's test, at $5 \%$ probability. Principal component analysis (Jackson, 1991) was performed to classify the cultivars that showed the maximum similarity and minimum dissimilarity among groups. Statistical analysis was performed in the software Statistica version 7.0 (Statsoft, 2004).

\section{Results and Discussion}

\section{Feeding preference assays}

In the free-choice test, significant differences were found in treatment attractiveness to S. eridania larvae in all time intervals evaluated except at 1 minute after the onset of the experiment (Table 1). At the 3-, 5-, 10-, 15-, 30-, 60-, and, 120-min intervals, cultivar BR17 Gurgueia was the least attractive to S. eridania larvae, differing significantly from BRS Novaera, which was the most attracted (Table 1). At 15, 60, and $120 \mathrm{~min}$, the cultivar BRS Milênio was significantly also more attractive than the other cultivars, not differing however from BRS Novaera (Table 1).

Based on these results, we can infer that cultivar BR17 Gurgueia probably possesses chemical and/or morphological traits that act as repellents, suppressants or deterrents to $S$. eridania larvae; in addition, these negative stimuli in BR17 Gurgueia may also be allied to the presence of positive stimuli in the other cowpea cultivars, which ultimately made most larvae to head in the opposite direction of BR17 Gurgueia in the free-choice assay.

Regarding the doses of neem, there was no significant difference in the attractiveness to S. eridania in the free-choice test; neem-treated leaf 
Table 1. Average number of fourth-instar Spodoptera eridania larvae attracted at different time intervals to cowpea cultivars treated with doses of neem oil in the free-choice test. Jaboticabal, SP State, Brazil, 2010.

\begin{tabular}{|c|c|c|c|c|c|c|c|c|c|}
\hline \multirow{2}{*}{ Cultivars (C) } & \multicolumn{9}{|c|}{ Minutes $^{1}$} \\
\hline & 1 & 3 & 5 & 10 & 15 & 30 & 60 & 120 & 360 \\
\hline Sempre Verde & $0.73 \mathrm{a}$ & $1.00 \mathrm{ab}$ & $0.93 \mathrm{ab}$ & $0.80 \mathrm{ab}$ & $0.80 \mathrm{ab}$ & $0.73 a b$ & $0.60 \mathrm{ab}$ & $0.60 \mathrm{abc}$ & $0.93 \mathrm{ab}$ \\
\hline BR17 Gurgueia & $0.13 \mathrm{a}$ & $0.13 \mathrm{a}$ & $0.07 \mathrm{a}$ & $0.00 \mathrm{a}$ & $0.00 \mathrm{a}$ & $0.20 \mathrm{a}$ & $0.07 \mathrm{a}$ & $0.07 \mathrm{a}$ & $0.13 \mathrm{a}$ \\
\hline BR3 Tracuateua & $0.27 \mathrm{a}$ & $0.27 \mathrm{ab}$ & $0.27 \mathrm{ab}$ & $0.27 \mathrm{ab}$ & $0.40 \mathrm{ab}$ & $0.27 \mathrm{a}$ & $0.33 \mathrm{ab}$ & $0.33 \mathrm{ab}$ & $0.27 \mathrm{ab}$ \\
\hline BRS Milênio & $0.73 \mathrm{a}$ & $1.07 \mathrm{ab}$ & $0.87 \mathrm{ab}$ & $1.00 \mathrm{ab}$ & $1.20 \mathrm{~b}$ & $0.93 a b$ & $1.40 \mathrm{~b}$ & $1.47 \mathrm{c}$ & $1.27 \mathrm{~b}$ \\
\hline BRS Novaera & $1.20 \mathrm{a}$ & $1.30 \mathrm{~b}$ & $1.40 \mathrm{~b}$ & $1.33 \mathrm{~b}$ & $1.33 \mathrm{~b}$ & $1.47 \mathrm{~b}$ & $1.40 \mathrm{~b}$ & $1.20 \mathrm{bc}$ & $1.07 \mathrm{ab}$ \\
\hline BRS Urubuquara & $0.40 \mathrm{a}$ & $0.73 \mathrm{ab}$ & $0.60 \mathrm{ab}$ & $0.67 \mathrm{ab}$ & $0.60 \mathrm{ab}$ & $0.60 \mathrm{ab}$ & $0.80 \mathrm{ab}$ & $0.80 \mathrm{abc}$ & $0.40 \mathrm{ab}$ \\
\hline \multicolumn{10}{|l|}{ Doses (D) } \\
\hline $0.35 \%$ & $0.47 \mathrm{a}$ & $0.87 \mathrm{a}$ & $0.60 \mathrm{a}$ & $0.63 \mathrm{a}$ & $0.80 \mathrm{a}$ & $0.77 \mathrm{a}$ & $0.77 \mathrm{a}$ & $0.67 \mathrm{a}$ & $0.60 \mathrm{a}$ \\
\hline $0.7 \%$ & $0.47 \mathrm{a}$ & $0.47 \mathrm{a}$ & $0.47 \mathrm{a}$ & $0.53 \mathrm{a}$ & $0.57 \mathrm{a}$ & $0.53 \mathrm{a}$ & $0.67 \mathrm{a}$ & $0.90 \mathrm{a}$ & $0.67 \mathrm{a}$ \\
\hline Control (water) & $0.80 \mathrm{a}$ & $0.93 \mathrm{a}$ & $1.00 \mathrm{a}$ & $0.87 \mathrm{a}$ & $0.80 \mathrm{a}$ & $0.80 \mathrm{a}$ & $0.87 \mathrm{a}$ & $0.67 \mathrm{a}$ & $0.77 \mathrm{a}$ \\
\hline $\mathrm{F}(\mathrm{C})$ & $2.16^{\mathrm{NS}}$ & $2.60 *$ & $2.99 *$ & $3.03 *$ & $3.04 *$ & $2.81^{*}$ & $4.20 * *$ & $4.47 * *$ & $2.96 *$ \\
\hline $\mathrm{F}(\mathrm{D})$ & 0.53 NS & $1.21^{\mathrm{NS}}$ & $0.80^{\mathrm{NS}}$ & $0.30^{\mathrm{NS}}$ & $0.19^{\mathrm{NS}}$ & $0.32^{\mathrm{NS}}$ & $0.24^{\mathrm{NS}}$ & $0.33^{\mathrm{NS}}$ & $0.17^{\mathrm{NS}}$ \\
\hline $\mathrm{F}(\mathrm{C} \times \mathrm{D})$ & $0.55^{\mathrm{NS}}$ & $1.02^{\mathrm{NS}}$ & $1.23^{\mathrm{NS}}$ & $0.60^{\mathrm{NS}}$ & $0.89^{\mathrm{NS}}$ & $0.44^{\mathrm{NS}}$ & $0.67^{\mathrm{NS}}$ & $0.86^{\mathrm{NS}}$ & $0.85^{\mathrm{NS}}$ \\
\hline
\end{tabular}

${ }^{1}$ Means followed by the same letter in a column do not differ significantly by Tukey's test at $5 \%$ probability. For analysis, data were transformed to $(x+0.5)^{1 / 2}$. NS $=$ not significant; $*$ significant at $5 \% ; * *=$ significant at $1 \%$.

discs were equally attracted by the larvae compared to leaf discs treated with water (control) (Table 1). In the no-choice test, there were no differences among either cultivars or doses of neem oil for the attractiveness to $S$. eridania larvae at any time interval assessed (Table 2).

The cultivar Sempre Verde was the most consumed by $S$. eridania larvae in the free-choice test, with $1.24 \mathrm{~cm}^{2}$, whereas cultivars BRS Urubuquara and BR17 Gurgueia were the least consumed, with 0.24 and $0.25 \mathrm{~cm}^{2}$, respectively (Table 3 ). All cowpea cultivars were equally consumed in the no-choice test (Table 3).

In both feeding preference tests, treatment without application of neem oil (controls) had the highest leaf intake, differing from treatments

Table 2. Average number of fourth-instar Spodoptera eridania larvae attracted at different time intervals to cowpea cultivars treated with doses of neem oil in the no-choice test. Jaboticabal, SP State, Brazil, 2010.

\begin{tabular}{lccccccccc}
\hline Cultivars (C) & \multicolumn{7}{c}{ Minutes $^{1}$} \\
\cline { 2 - 9 } & 1 & 3 & 5 & 10 & 15 & 30 & 60 & 120 & 360 \\
\hline Sempre Verde & $0.33 \mathrm{a}$ & $0.33 \mathrm{a}$ & $0.40 \mathrm{a}$ & $0.40 \mathrm{a}$ & $0.33 \mathrm{a}$ & $0.33 \mathrm{a}$ & $0.40 \mathrm{a}$ & $0.47 \mathrm{a}$ & $0.47 \mathrm{a}$ \\
BR17 Gurgueia & $0.20 \mathrm{a}$ & $0.33 \mathrm{a}$ & $0.40 \mathrm{a}$ & $0.40 \mathrm{a}$ & $0.40 \mathrm{a}$ & $0.53 \mathrm{a}$ & $0.60 \mathrm{a}$ & $0.53 \mathrm{a}$ & $0.60 \mathrm{a}$ \\
BR3 Tracuateua & $0.53 \mathrm{a}$ & $0.53 \mathrm{a}$ & $0.53 \mathrm{a}$ & $0.60 \mathrm{a}$ & $0.53 \mathrm{a}$ & $0.40 \mathrm{a}$ & $0.67 \mathrm{a}$ & $0.60 \mathrm{a}$ & $0.40 \mathrm{a}$ \\
BRS Milênio & $0.67 \mathrm{a}$ & $0.67 \mathrm{a}$ & $0.50 \mathrm{a}$ & $0.47 \mathrm{a}$ & $0.73 \mathrm{a}$ & $0.80 \mathrm{a}$ & $0.73 \mathrm{a}$ & $0.67 \mathrm{a}$ & $0.73 \mathrm{a}$ \\
BRS Novaera & $0.47 \mathrm{a}$ & $0.53 \mathrm{a}$ & $0.40 \mathrm{a}$ & $0.47 \mathrm{a}$ & $0.33 \mathrm{a}$ & $0.47 \mathrm{a}$ & $0.73 \mathrm{a}$ & $0.67 \mathrm{a}$ & $0.73 \mathrm{a}$ \\
BRS Urubuquara & $0.47 \mathrm{a}$ & $0.60 \mathrm{a}$ & $0.60 \mathrm{a}$ & $0.60 \mathrm{a}$ & $0.53 \mathrm{a}$ & $0.53 \mathrm{a}$ & $0.67 \mathrm{a}$ & $0.53 \mathrm{a}$ & $0.40 \mathrm{a}$ \\
\hline Doses (D) & & & & & & & & $0.73 \mathrm{a}$ & $0.70 \mathrm{a}$ \\
\hline $0.35 \%$ & $0.40 \mathrm{a}$ & $0.40 \mathrm{a}$ & $0.40 \mathrm{a}$ & $0.37 \mathrm{a}$ & $0.37 \mathrm{a}$ & $0.47 \mathrm{a}$ & $0.73 \mathrm{a}$ & $0.67 \mathrm{a}$ \\
$0.7 \%$ & $0.47 \mathrm{a}$ & $0.53 \mathrm{a}$ & $0.53 \mathrm{a}$ & $0.57 \mathrm{a}$ & $0.50 \mathrm{a}$ & $0.47 \mathrm{a}$ & $0.63 \mathrm{a}$ & $0.50 \mathrm{a}$ & $0.43 \mathrm{a}$ \\
Control (water) & $0.47 \mathrm{a}$ & $0.57 \mathrm{a}$ & $0.43 \mathrm{a}$ & $0.53 \mathrm{a}$ & $0.57 \mathrm{a}$ & $0.60 \mathrm{a}$ & $0.53 \mathrm{a}$ & $0.57 \mathrm{a}$ & $0.53 \mathrm{a}$ \\
\hline F (C) & $1.62^{\mathrm{NS}}$ & $1.14^{\mathrm{NS}}$ & $0.46^{\mathrm{NS}}$ & $0.48^{\mathrm{NS}}$ & $1.45^{\mathrm{NS}}$ & $1.60^{\mathrm{NS}}$ & $0.99^{\mathrm{NS}}$ & $0.38^{\mathrm{NS}}$ & $1.50^{\mathrm{NS}}$ \\
F (D) & $0.18^{\mathrm{NS}}$ & $0.92^{\mathrm{NS}}$ & $0.57^{\mathrm{NS}}$ & $1.38^{\mathrm{NS}}$ & $1.24^{\mathrm{NS}}$ & $0.70^{\mathrm{NS}}$ & $1.29^{\mathrm{NS}}$ & $0.85^{\mathrm{NS}}$ & $2.24^{\mathrm{NS}}$ \\
F (C x D) & $0.69^{\mathrm{NS}}$ & $1.41^{\mathrm{NS}}$ & $1.06^{\mathrm{NS}}$ & $1.30^{\mathrm{NS}}$ & $0.79^{\mathrm{NS}}$ & $1.40^{\mathrm{NS}}$ & $0.81^{\mathrm{NS}}$ & $0.56^{\mathrm{NS}}$ & $0.50^{\mathrm{NS}}$ \\
\hline
\end{tabular}

${ }^{1}$ Means followed by the same letter in a column do not differ significantly by Tukey's test at $5 \%$ probability. For analysis, data were transformed to $(x+0.5)^{1 / 2}$. NS $=$ not significant. 
Table 3. Leaf area consumed by fourth-instar Spodoptera eridania larvae in cowpea cultivars treated with doses of neem oil in free-choice and no-choice tests. Jaboticabal, SP State, Brazil, 2010.

\begin{tabular}{lll}
\hline \multirow{2}{*}{ Cultivars (C) } & \multicolumn{2}{c}{ Leaf area consumed $\left(\mathrm{cm}^{2}\right)^{1}$} \\
\cline { 2 - 3 } & Free-choice & No-choice \\
\hline Sempre Verde & $1.24 \mathrm{c}$ & $0.66 \mathrm{a}$ \\
BR17 Gurgueia & $0.25 \mathrm{ab}$ & $0.80 \mathrm{a}$ \\
BR3 Tracuateua & $0.40 \mathrm{abc}$ & $0.79 \mathrm{a}$ \\
BRS Milênio & $1.08 \mathrm{bc}$ & $0.54 \mathrm{a}$ \\
BRS Novaera & $0.90 \mathrm{abc}$ & $0.72 \mathrm{a}$ \\
BRS Urubuquara & $0.24 \mathrm{a}$ & $0.90 \mathrm{a}$ \\
\hline Doses (D) & & \\
\hline 0.35\% & $0.49 \mathrm{a}$ & $0.48 \mathrm{a}$ \\
0.7\% & $0.53 \mathrm{a}$ & $0.63 \mathrm{a}$ \\
Control (water) & $1.05 \mathrm{~b}$ & $1.10 \mathrm{~b}$ \\
\hline F (C) & $4.53 * *$ & $0.26 \mathrm{Ns}$ \\
F (D) & $3.30 *$ & $2.97 *$ \\
F (C x D) & $0.79 \mathrm{NS}$ & 1.73 \\
\hline
\end{tabular}

${ }^{1}$ Means followed by the same letter in a column do not differ significantly by Tukey's test at $5 \%$ probability. For analysis, data were transformed to $(\mathrm{x}+0.5)^{1 / 2}$. ${ }^{\mathrm{NS}}=$ not significant; $* *=$ significant at $1 \%$.

submitted to application of the natural product at 0.35 and $0.7 \%$, which were less consumed (Table 3 ). Significant differences in leaf consumption were not observed between doses of neem oil (Table 3).

The lesser consumption of $S$. eridania larvae in the neem-treated leaf discs is probably due to the presence of deterrent factors intrinsic to the active ingredients of the botanical insecticide (Torres; Barros; Oliveira, 2001), mainly azadiracthin.
Medeiros \& Boiça Júnior (2005) reported that when there is no option to choose among untreated leaves, larvae may consume leaves treated with different concentrations of botanical insecticides, however with lower consumption, hence reducing the injury caused to the plants.

There were no significant differences among the cowpea cultivars and doses of neem oil on attractiveness to $S$. eridania larvae and leaf area consumed in the free-choice and no-choice tests (Tables 1, 2 and 3).

\section{Evaluation of biological aspects}

In the biological parameter assay, cowpea cultivars affected differently the development of $S$. eridania (Tables 4 and 5). On the other hand, duration and survival of larvae, pre-pupae, and pupae, duration of the larva-to-adult period, longevity of adults, sex ratio, weights of 15-day-old larvae and 24-hour-old pupae were not possible to be analyzed statistically for the effects of doses of neem oil due to complete larval mortality (Tables 4 and 5).

The cultivar BRS Novaera showed the longest duration of larval period, with 23.82 days, differing from the cultivars BRS Urubuquara and Sempre Verde, which provided the shortest larval period, 20.13 and 21.21 days, respectively (Table 4). However, duration of $S$. eridania larval period on cowpea cultivars in the current study were in general longer than the duration on morning glory, cotton, and soybean leaves, with 15.7, 15.9 , and 18.3 days, respectively (Santos; Neves; Meneguim, 2005).

Table 4. Duration (days) and survival (\%) of larvae, pre-pupae, and pupae, and duration (days) of the larva-to-adult period of Spodoptera eridania fed on leaves of cowpea cultivars. Jaboticabal, SP State, Brazil, 2010.

\begin{tabular}{|c|c|c|c|c|c|c|c|}
\hline \multirow[b]{2}{*}{ Cutivars (C) } & \multicolumn{2}{|c|}{ Larvae } & \multicolumn{2}{|c|}{ Pre-pupae } & \multicolumn{2}{|c|}{ Pupae } & \multirow{2}{*}{$\begin{array}{l}\text { Larva-to-adult } \\
\text { period (days) }{ }^{1}\end{array}$} \\
\hline & $\begin{array}{l}\text { Period } \\
(\text { days })^{1}\end{array}$ & $\begin{array}{c}\text { Viability } \\
(\%)^{2}\end{array}$ & $\begin{array}{l}\text { Period } \\
\text { (days) }^{1}\end{array}$ & $\begin{array}{c}\text { Viability } \\
(\%)^{2}\end{array}$ & $\begin{array}{l}\text { Period } \\
{\text { (days })^{1}}^{1}\end{array}$ & $\begin{array}{c}\text { Viability } \\
(\%)^{2}\end{array}$ & \\
\hline Sempre Verde & $21.21 \mathrm{a}$ & $80.0 \mathrm{a}$ & $2.36 \mathrm{ab}$ & $100.00 \mathrm{a}$ & $12.50 \mathrm{a}$ & $43.00 \mathrm{bc}$ & $39.00 \mathrm{a}$ \\
\hline BR17 Gurgueia & $22.64 \mathrm{ab}$ & $70.0 \mathrm{a}$ & $3.09 \mathrm{~b}$ & $92.00 \mathrm{a}$ & $13.50 \mathrm{a}$ & $18.00 \mathrm{c}$ & -3 \\
\hline BR3 Tracuateua & $22.58 \mathrm{ab}$ & $60.0 \mathrm{a}$ & $1.67 \mathrm{a}$ & $100.00 \mathrm{a}$ & $13.00 \mathrm{a}$ & $67.00 \mathrm{abc}$ & $40.25 \mathrm{a}$ \\
\hline BRS Milênio & $21.84 \mathrm{ab}$ & $95.0 \mathrm{a}$ & $2.37 \mathrm{ab}$ & $100.00 \mathrm{a}$ & $12.73 \mathrm{a}$ & $79.00 \mathrm{ab}$ & $39.53 \mathrm{a}$ \\
\hline BRS Novaera & $23.82 \mathrm{~b}$ & $70.0 \mathrm{a}$ & $2.82 \mathrm{~b}$ & $85.00 \mathrm{a}$ & $13.00 \mathrm{a}$ & $18.00 \mathrm{c}$ & -3 \\
\hline BRS Urubuquara & $20.13 \mathrm{a}$ & $75.0 \mathrm{a}$ & $1.87 \mathrm{ab}$ & $100.00 \mathrm{a}$ & $12.79 \mathrm{a}$ & $93.00 \mathrm{a}$ & $38.57 \mathrm{a}$ \\
\hline $\mathrm{F}(\mathrm{C})$ & $4.22 * *$ & $1.51 \mathrm{NS}$ & $2.53 *$ & $1.73^{\mathrm{NS}}$ & $0.36^{\mathrm{NS}}$ & $7.46 * *$ & $2.18^{\mathrm{NS}}$ \\
\hline
\end{tabular}

Means followed by the same letter a in column do not differ significantly by Tukey's test at $5 \%$ probability. ${ }^{1}$ For analysis, data were transformed to $(x+0.5)^{1 / 2} .{ }^{2}$ For analysis, data were transformed to $\arcsin (\mathrm{x} / 100)^{1 / 2} \cdot{ }^{3}$ Insufficient number of replications for statistical analysis (nil variance). ${ }^{\mathrm{NS}}=$ not significant; $*=$ significant at $5 \% ; * *=$ significant at $1 \%$. 
Table 5. Weight ( $\mathrm{g}$ ) of larvae and pupae, longevity (days) of adults, and sex ratio of Spodoptera eridania fed on leaves of cowpea cultivars. Jaboticabal, SP State, Brazil, 2011.

\begin{tabular}{|c|c|c|c|c|}
\hline \multirow{2}{*}{ Cultivars (C) } & \multicolumn{2}{|c|}{ Weight $(\mathrm{g})^{1}$} & \multirow{2}{*}{$\begin{array}{c}\text { Longevity } \\
\text { (days) }^{1}\end{array}$} & \multirow{2}{*}{$\begin{array}{c}\text { Sex } \\
\text { ratio }^{1}\end{array}$} \\
\hline & Larvae & Pupae & & \\
\hline Sempre verde & $0.32 \mathrm{bc}$ & $0.16 \mathrm{ab}$ & $5.33 \mathrm{a}$ & $0.46 \mathrm{a}$ \\
\hline BR17 Gurgueia & $0.28 \mathrm{ab}$ & $0.20 \mathrm{a}$ & -2 & $0.36 \mathrm{a}$ \\
\hline BR3 Tracuateua & $0.27 \mathrm{ab}$ & $0.25 \mathrm{~b}$ & $4.87 \mathrm{a}$ & $0.67 \mathrm{a}$ \\
\hline BRS Milênio & $0.31 \mathrm{bc}$ & $0.21 \mathrm{ab}$ & $5.27 \mathrm{a}$ & $0.53 \mathrm{a}$ \\
\hline BRS Novaera & $0.17 \mathrm{a}$ & $0.19 \mathrm{a}$ & -2 & $0.36 \mathrm{a}$ \\
\hline BRS Urubuquara & $0.43 \mathrm{c}$ & $0.23 \mathrm{ab}$ & $5.64 \mathrm{a}$ & $0.33 \mathrm{a}$ \\
\hline $\mathrm{F}(\mathrm{C})$ & $6.67 * *$ & $2.59 *$ & $0.90^{\mathrm{NS}}$ & $0.82^{\mathrm{NS}}$ \\
\hline
\end{tabular}

Means followed by the same letter in a column do not differ significantly by Tukey's test at $5 \%$ probability. ${ }^{1}$ For analysis, data were transformed to $(x+0.5)^{1 / 2} \cdot{ }^{2}$ Insufficient number of replications for statistical analysis (nil variance). ${ }^{\mathrm{NS}}=$ not significant; $*=$ significant at $5 \% ; * *=$ significant at $1 \%$.

The duration of the period of pre-pupae showed the same trend observed in the larval period; cultivar BRS Novaera differed from the other cultivars, showing the longest mean duration with 2.82 days (Table 4). The duration of pre-pupae ranged between 1.67 and 3.09 days, means higher than those found by Souza et al. (2014b) while evaluating the development of S. eridania on soybean genotypes, which ranged from 1.31 to 1.86 days.

For the pupal period there was no statistical difference among cultivars, with mean durations varying from 12.5 to 13.5 days (Table 4). Similar to the values found for pre-pupal stage, Santos; Neves; Meneguim (2005) reported lower values than those reported in this survey, with durations of $8.4,8.9$, and 8.8 days when $S$. eridania were reared on leaves of cotton, soybeans, and morning glory, respectively. Higher means found for the periods of larvae, pre-pupae, and pupae in the present study is possibly because cowpea is a less preferred host for the development of $S$. eridania. However, these parameters were statistically analyzed using only the treatments without the application of neem oil, since the other treatments did not have enough data to analyze due to complete death of larvae.

Survival of the stages of larvae and pre-pupae did not differ statistically among the cowpea cultivars (Table 4). However, pupae whose larvae were fed leaves of the cultivars BR17 Gurgueia and BRS Novaera had survival negatively affected (18\% survival on both cultivars), whereas BRS
Urubuquara provided better pupal development (93\% survival) (Table 4).

Regarding the duration of the larva-to-adult period of S. eridania, means from 38.57 to 40.25 days were found, however there were no significant differences among cultivars (Table 4). Parra; Precetti; Kasten Junior (1977) observed durations of the complete biological cycle of 28.02 days in cotton and 34.28 days in soybean plants.

For the weight of 15-day-old larvae and 24-hour-old pupae, we verified that cultivar BRS Novaera exhibited the lowest means, 0.17 and $0.19 \mathrm{~g}$, respectively, differing from cultivar BRS Urubuquara for larval weight and BR3 Tracuateua for pupal weight, which had the highest means, 0.43 and $0.25 \mathrm{~g}$, respectively (Table 5).

The sex ratio of $S$. eridania did not show significant differences, and ranged from 0.33 to 0.67 (Table 5). Similar values were observed by Santos; Neves; Meneguim (2005) on soybeans, cotton, and morning glory, where this biological parameter varied from 0.41 to 0.47 . Thus, we can affirm the evaluated cowpea cultivars did not affect the sexual proportion of $S$. eridania, which was around 1:1.

The cowpea cultivars behaved similarly regarding S. eridania adult longevity (Table 5), with average durations of 4.87 to 5.64 days, differing from the results obtained by Souza et al. (2014b), who observed shorter $S$. eridania adult longevity, from 2.93 to 4.07 days on soybean genotypes. However, cultivars BRS Novaera and BR17 Gurgueia were less suitable to $S$. eridania development, since there were not enough emerged adults to be included in the statistical analysis (Table 5).

The mean mortality of S. eridania larvae showed significant differences at 3, 6, and 12 days after the onset of the experiment (Table 6). At 3 days, BRS Milênio was the cultivar that produced the highest mortality of S. eridania, with $13.33 \%$, whereas the lowest mortality rates were found on the cultivars Sempre Verde, BR3 Tracuateua, and BRS Urubuquara, with $0,1.67$, and $1.67 \%$, respectively (Table 6 ). At the sixth day, cultivars BRS Milênio, BRS Novaera, and BRS Urubuquara caused the highest mortality (from 66.67 to $68.83 \%$ ), and BR17 Gurgueia exhibited the lowest mortality (30\%) (Table 6). On cultivars BRS Milênio, BRS Novaera, and BRS Urubuquara, the highest percentages of mortality were found after 12 days (from 66.67 to $68.33 \%$ ), whereas on Sempre Verde and BR17 Gurgueia were found the lowest mortality of S. eridania (48.33 
and 50\%, respectively) (Table 6). Santos; Neves; Meneguim (2005), studying survival of fourth-instar S. eridania larvae reared on soybeans, cotton, and morning glory found $93.6,96.4$, and $100 \%$ survival, respectively, showing that these hosts were suitable to development of the southern armyworm. Bavaresco et al. (2003) in a comparative biological assay of Spodoptera cosmioides (Walker) (Lepidoptera: Noctuidae) on common beans, soybeans, onions, and castor beans, observed larval mortality of 94.7, $54.7,26$, and $22.7 \%$, respectively; in the last host, the low survival was explained by the presence of morphological characteristics such as pilosity, which caused high mortality of the insects during the larval stage.

There was significant differences in S. eridania larval mortality at 3,6,12, and 24 days after the application of different doses of neem oil (Table 6). At 3 days higher mortality was found for the dose of $0.7 \%$, with $12.5 \%$, differing significantly from the lower concentration and control (Table 6). At 6, 12 , and 24 days there were no significant differences between the doses of 0.35 and $0.7 \%$ on larval mortality, and both differed from the control; the highest concentration of $A$. indica produced $100 \%$ control of S. eridania larvae after 24 days (Table 6). Rosseti et al. (2008), evaluating the biological activity

Table 6. Average mortality (\%) of Spodoptera eridania larvae on cowpea cultivars at $3,6,12$, and 24 days after application of neem oil. Jaboticabal, SP State, Brazil, 2011.

\begin{tabular}{lcccr}
\hline \multirow{2}{*}{ Cultivars (C) } & \multicolumn{4}{c}{ Mortality $(\%)^{1}$} \\
\cline { 2 - 5 } & 3 days & 6 days & 12 days & 24 days \\
\hline Sempre Verde & $0.00 \mathrm{a}$ & $48.33 \mathrm{~b}$ & $48.33 \mathrm{a}$ & $73.33 \mathrm{a}$ \\
BR17 Gurgueia & $3.33 \mathrm{ab}$ & $30.00 \mathrm{a}$ & $50.00 \mathrm{a}$ & $76.67 \mathrm{a}$ \\
BR3 Tracuateua & $1.67 \mathrm{a}$ & $60.00 \mathrm{bc}$ & $60.00 \mathrm{ab}$ & $80.00 \mathrm{a}$ \\
BRS Milênio & $13.33 \mathrm{~b}$ & $66.67 \mathrm{c}$ & $66.67 \mathrm{~b}$ & $68.33 \mathrm{a}$ \\
BRS Novaera & $10.00 \mathrm{ab}$ & $66.67 \mathrm{c}$ & $66.67 \mathrm{~b}$ & $73.33 \mathrm{a}$ \\
BRS Urubuquara & $1.67 \mathrm{a}$ & $68.33 \mathrm{c}$ & $68.33 \mathrm{~b}$ & $75.00 \mathrm{a}$ \\
\hline Doses (D) & & & & \\
\hline $0.35 \%$ & $1.67 \mathrm{a}$ & $87.50 \mathrm{~b}$ & $87.50 \mathrm{~b}$ & $98.33 \mathrm{~b}$ \\
$0.7 \%$ & $12.50 \mathrm{~b}$ & $80.00 \mathrm{~b}$ & $90.00 \mathrm{~b}$ & $100.00 \mathrm{~b}$ \\
Control (water) & $0.83 \mathrm{a}$ & $2.50 \mathrm{a}$ & $2.50 \mathrm{a}$ & $25.00 \mathrm{a}$ \\
\hline F (C) & $4.27 * *$ & $22.04 * *$ & $6.92 * *$ & $1.36^{\mathrm{NS}}$ \\
F (D) & $12.51 * *$ & $432.79 * *$ & $435.17 * *$ & $328.73^{* *}$ \\
F (C x D) & $3.24 * *$ & $12.19^{* *}$ & $1.58^{\mathrm{NS}}$ & $1.66^{\mathrm{NS}}$ \\
\hline
\end{tabular}

Means followed by the same letter in a column do not differ significantly by Tukey's test at $5 \%$ probability. For analysis, data were transformed to $\arcsin (\mathrm{x} / 100)^{1 / 2} .{ }^{\mathrm{NS}}=$ not significant; $* *=$ significant at $1 \%$. of Melia azedarach L. (Meliaceae) on S. eridania larvae, concluded that its insecticidal extracts should be incorporated in management programs for this pest since the leaf extracts at the concentrations of 2,5 , and $10 \%$ were effective, reducing the food intake and larval weight.

Significant differences were observed for the cultivar x doses interaction on S. eridania mortality at 3 and 6 days after the beginning of the experiment (Table 6). At the third day, there was no significant difference among untreated cowpea cultivars and cultivars treated with neem oil at $0.35 \%$, whereas for leaf discs treated with the dose of $0.7 \%$, highest mortality was found for the larvae fed on BRS Milênio and BRS Novaera, with respective mortality of 35 and $25 \%$, differing significantly from the other cultivars (Table 7).

Analyzing the effect of cowpea cultivars on each dose of neem oil 6 days after application, we found that in all cultivars except BR17 Gurgueia, both doses of neem oil were efficient in the mortality of $S$. eridania larvae, differing significantly from the control (Table 8). With respect to the effect of the doses on the cultivars, using $0.35 \%$ neem oil on BRS Milênio and BRS Urubuquara produced the highest mortality of $S$. eridania larvae, whereas with $0.7 \%$, in addition to these cultivars a higher mortality rate was also found in BRS Novaera (all with $100 \%$ control) (Table 8). In the absence of neem oil (control) there was no significant difference among the cowpea cultivars (Table 8). Thuler et al. (2008) evaluated the interaction of cabbage cultivars

Table 7. Interaction of cowpea cultivars $\mathrm{x}$ doses of neem oil on mortality (\%) of Spodoptera eridania larvae at 3 days after application. Jaboticabal, SP State, Brazil, 2011.

\begin{tabular}{lcccc}
\hline & \multicolumn{3}{c}{ Doses (D) $^{1}$} \\
\cline { 2 - 4 } Cultivars (C) & $0.35 \%$ & $0.7 \%$ & $\begin{array}{c}\text { Control } \\
\text { (water) }\end{array}$ & F (C) \\
\hline Sempre Verde & $0.00 \mathrm{aA}$ & $0.00 \mathrm{aA}$ & $0.00 \mathrm{aA}$ & $0.00 \mathrm{NS}$ \\
BR17 Gurgueia & $0.00 \mathrm{aA}$ & $10.00 \mathrm{abA}$ & $0.00 \mathrm{aA}$ & $1.64 \mathrm{NS}$ \\
BR3 Tracuateua & $5.00 \mathrm{aA}$ & $0.00 \mathrm{aA}$ & $0.00 \mathrm{aA}$ & $0.41^{\mathrm{NS}}$ \\
BRS Milênio & $5.00 \mathrm{aA}$ & $35.00 \mathrm{cB}$ & $0.00 \mathrm{aA}$ & $17.63 * *$ \\
BRS Novaera & $0.00 \mathrm{aA}$ & $25.00 \mathrm{bcB}$ & $5.00 \mathrm{aA}$ & $8.61 * *$ \\
BRS Urubuquara & $0.00 \mathrm{aA}$ & $5.00 \mathrm{aA}$ & $0.00 \mathrm{aA}$ & $0.41^{\mathrm{NS}}$ \\
F (D) & $0.33 \mathrm{NS}$ & $10.21 * *$ & $0.21 \mathrm{NS}$ & - \\
\hline
\end{tabular}

${ }^{1}$ Means followed by the same letter, lower case for columns and upper case for rows, do not differ significantly by Tukey's test at 5\% probability. For analysis, data were transformed to $\arcsin (\mathrm{x} / 100)^{1 / 2}$. NS $=$ not significant; $* *=$ significant at $1 \%$. 
Table 8. Interaction of cowpea cultivars $\mathrm{x}$ doses of neem oil on mortality (\%) of Spodoptera eridania larvae at 6 days after application. Jaboticabal, SP State, Brazil, 2011.

\begin{tabular}{lcccc}
\hline & \multicolumn{3}{c}{ Doses (D) $)^{1}$} \\
\cline { 2 - 4 } Cultivars (C) & $0.35 \%$ & $0.7 \%$ & $\begin{array}{c}\text { Control } \\
\text { (water) }\end{array}$ \\
\hline Sempre Verde & $70.00 \mathrm{aB}$ & $75.00 \mathrm{bB}$ & $0.00 \mathrm{aA}$ & $57.27 * *$ \\
BR17 Gurgueia & $80.00 \mathrm{abB}$ & $10.00 \mathrm{aA}$ & $0.00 \mathrm{aA}$ & $61.89 * *$ \\
BR3 Tracuateua & $85.00 \mathrm{abB}$ & $95.00 \mathrm{bcB}$ & $0.00 \mathrm{aA}$ & $88.76 * *$ \\
BRS Milênio & $100.00 \mathrm{bB}$ & $100.00 \mathrm{cB}$ & $0.00 \mathrm{aA}$ & $108.57 * *$ \\
BRS Novaera & $90.00 \mathrm{abB}$ & $100.00 \mathrm{cB}$ & $10.00 \mathrm{aA}$ & $79.26 * *$ \\
BRS Urubuquara & $100.00 \mathrm{bB}$ & $100.00 \mathrm{cB}$ & $5.00 \mathrm{aA}$ & $97.99 * *$ \\
F (D) & $4.48 * *$ & $41.37 * *$ & $0.57 \mathrm{NS}$ & - \\
\hline
\end{tabular}

${ }^{1}$ Means followed by the same letter, lower case for columns and upper case for rows, do not differ significantly by Tukey's test, at $5 \%$ probability. For analysis, data were transformed to $\arcsin (\mathrm{x} / 100)^{1 / 2} \cdot{ }^{\mathrm{NS}}=$ not significant; $* *=$ significant at $1 \%$.

and natural products and concluded that the effect of the cultivars on larval mortality of the diamondback moth was observed only using the pyroligneous acid extract, and cultivar Chato de Quintal exhibited a positive interaction with the product, increasing mortality relative to the other treatments.

The principal component analysis found that the first factor (Factor 1) explained $51.86 \%$ of the variability contained in the original variables; the

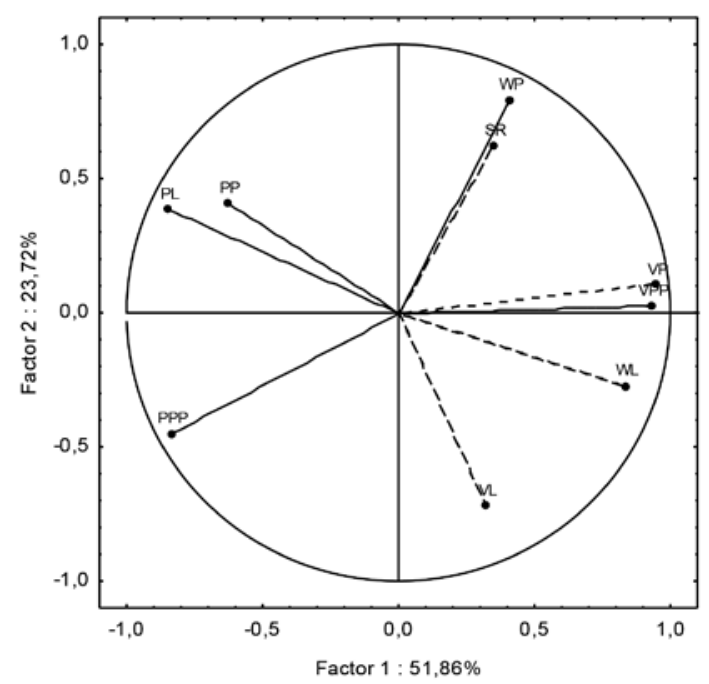

Figure 1. Distribution of the biological parameters according to the analysis of principal components obtained from Spodoptera eridania fed on leaves of cowpea cultivars. Period of larvae (PL); viability of larvae (VL); period of pre-pupae (PPP); viability of pre-pupae (VPP); period of pupae (PP); viability of pupae (VP); weight of larvae (WL); weight of pupae (WP); and sex ratio (SR). parameters that most influenced this factor were viability of pupae (0.94), viability of pre-pupae (0.93), period of larvae (-0.85), weight of larvae (0.83) and period of pupae $(-0.63)$. The second factor (Factor 2) explained $23.72 \%$ of the variability present in the original data, and the biological parameter that most influenced this factor was the weight of pupae (0.79) (Figure 1).

Analyzing the distribution of the cowpea cultivars according to the analysis of the principal components obtained from S. eridania, the lowest value of the period of pre-pupae and the highest of weight of pupae were the variable values that most influenced to isolate the cultivar BR3 Tracuateua in the first quadrant. The cultivars BR17 Gurgueia and BRS Novaera isolated in the third quadrant; they had the longest period of pre-pupae, and were lowest for viability and weight of pupae. Finally, lower values for period and weight of larvae and intermediate for period of pre-pupae and weight of pupae were the most relevant parameters to separate the cultivars Sempre Verde, BRS Milênio, and BRS Urubuquara in the fourth quadrant (Figure 2).

Using the distribution of the cowpea cultivars (Figure 2) and taking into account the results obtained for the biological parameters of $S$. eridania, they may be classified according to levels of resistance: BR17 Gurgueia and BRS Novaera were less suitable to the development of S. eridania; BR3 Tracuateua, susceptible; and Sempre Verde, Milênio, and BRS Urubuquara, highly susceptible.

The analysis of the principal components also indicated that the biological parameters of period of pupae, sex ratio, and viability of larvae were the

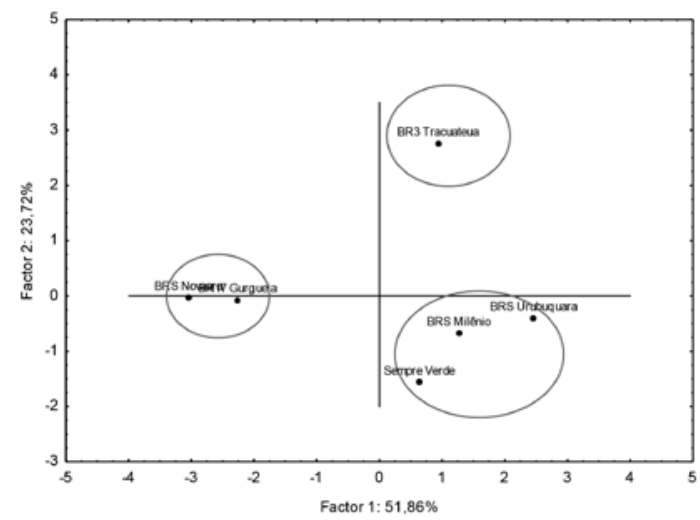

Figure 2. Distribution of cowpea cultivars according to the principal component analysis obtained from Spodoptera eridania fed on their leaves. 
variables that least influenced the differentiation and classification of the cowpea cultivars by levels of resistance to $S$. eridania (Figure 2).

Cultivar BR17 Gurgueia has chemical and/or morphological traits that act as negative stimuli to attractiveness of $S$. eridania larvae in free-choice feeding preference tests. When neem oil was applied at both doses, there was no difference in the attractiveness of $S$. eridania larvae in the freechoice and no-choice tests, demonstrating that the application of the natural product overlapped the effect of the cultivars, making the larvae behave equally regarding their attractiveness towards the cowpea leaf discs.

In both tests, cowpea leaf discs without application of neem oil (control) were more consumed by $S$. eridania larvae, differing from the treatments submitted to the application of $A$. indica. This demonstrates that the natural product causes a deterrent effect to $S$. eridania larvae. The insecticide plant also affected the development of S. eridania. In the first days after the start of the assay, the cultivar that caused highest mortality was BRS Milênio, and for the doses of A. indica, higher larval mortality was provided by the concentration of $0.7 \%$, which differed from the lower dose and control. However, during the course of the larval development smaller differences were observed among treatments, so that at the end of the larval stage there were no differences among cultivars or neem oil. These results suggest that the association of cultivar BRS Milênio and neem oil at $0.7 \%$ may provide an immediate and efficient synergic effect to control the southern armyworm.

\section{Conclusions}

Cultivars BRS Urubuquara and BR17 Gurgueia were the least consumed by S. eridania in the freechoice feeding preference assay.

The doses of 0.35 and $0.7 \%$ of neem oil reduced leaf consumption by $S$. eridania larvae; neem oil at both doses affected adversely $S$. eridania development; Cultivars BR17 Gurgueia and BRS Novaera were less suitable for S. eridania development; BR3 Tracuateua was susceptible; and Sempre Verde, Milênio, and BRS Urubuquara were highly susceptible to $S$. eridania.

\section{Literature Cited}

Aggarwal, N.; Holaschke, M.; Basedow, T.

2006. Evaluation of bio-ratioanal insecticides to control Helicoverpa armigera (Hübner) and Spodoptera exigua (Hübner) (Lepidoptera: Noctuidae) fed on Vicia faba L. Mitteilungen der Deutschen Gesellschaft für allgemeine und angewandte Entomologie, 15: 245-250.

Bavaresco, A.; Garcia, M.S.; Grützmacher, A.D.; Foresti, J.; Ringenberg, R.

2003. Biologia comparada de Spodoptera cosmioides (Walk.) (Lepidoptera: Noctuidae) em cebola, mamona, soja e feijão. Ciência Rural, 33(6): 993-998.

Boiça Júnior, A.L.; Silva, A.G.; Bottega, D.B.; Rodrigues, N.E.L.; Souza, B.H.S.; Peixoto, M.L.; Souza, J.R.

2011. Resistência de plantas e o uso de produtos naturais como táticas de controle no manejo integrado de pragas. In: Busoli, A.C.; Fraga, D.F.; Santos, L.C.; Alencar, J.R.C. C.; Grigolli, J.F.J.; Janini, J.C.; Souza, L.A.; Viana, M.A.; Funichello, M. (Ed.). Tópicos em Entomologia Agrícola IV. Jaboticabal: Gráfica e Editora Multipress. p. 139-158.

Brunherotto, R.; Vendramim, J.D.

2001. Bioatividade de extratos aquosos de Melia azedarach L. sobre o desenvolvimento de Tuta absoluta (Meyrick) (Lepidoptera: Gelechiidae) em tomateiro. Neotropical Entomology, 30(3): 455-459.

Capinera, J.L.

2005. Southern armyworm, Spodoptera eridania (Cramer) (Insecta: Lepidoptera: Noctuidae). University of Florida.
Available in: <http://entnemdept.ufl.edu/creatures/veg/leaf/ southern_armyworm.htm>. Consulted: 01/Abr/2012.

Carvalho, R.O.; Lima, A.C.S.; Alves, J.M.A.

2011. Resistência de genótipos de feijão-caupi ao Callosobruchus maculatus (Fabr.) (Coleoptera: Bruchidae).Revista Agro@ mbiente Online, 5(1): 50-56.

Costa, N.P.; Santos, T.M.; Boiça Júnior, A.L.

2004. Preferência para oviposição de Bemisia tabaci biótipo-B em genótipos de caupi. Acta Scientiarum. Agronomy, 26(2): 227-230.

Freire Filho, F.R.; Rocha, M.M.; Ribeiro, V.Q.; Sittolin, I.M. 2009. Avanços e perspectivas para a cultura do feijão-caupi. IN: Albuquerque, A.C.S.; Silva, A.G. (Ed.). Agricultura Tropical: quatro décadas de inovações tecnológicas, institucionais e políticas. Brasília: Embrapa Informação Tecnológica. Cap. 7, p. 235-250.

Greene, GL.; Leppla, N.C.; Dickerson, W.A.

1976. Velvet bean caterpillar: a rearing procedure and artificial medium. Journal of Economic Entomology, 69(4): 487-488.

International Federation of Organic Agriculture Movements. The IFOAM norms for organic production and processing: version 2005. Bonn, Germany: International Federation of Organic Agriculture Movements, 2007.

Jackson, J.E.

1991. A user's guide to principal components. New York: Wiley. 569 p. 
Lara, F.M.

1991. Princípios de resistência de plantas a insetos. 2. ed. São Paulo: Ícone. 336 p.

Liburd, O.E.; Funderburk, J.E.; Olson, S.M.

2000. Effect of biological and chemical insecticides on Spodoptera species (Lep., Noctuidae) and marketable yields of tomatoes. Journal of Applied Entomology, 124: 19-25.

Lima, M.P.L.; Oliveira, J.V.; Barros, R; Torres, J.B.; Gonçalves, M.E.C.

2002. Estabilidade da resistência de genótipos de caupi a Callosobruchus maculatus (Fabr.) em gerações sucessivas. Scientia Agricola, 59(2): 275-280.

Martinez, S.S.

2002. Situação atual e perspectivas do uso do nim no Brasil. In: O nim: Azadirachta indica - natureza, usos múltiplos, produção. Londrina: IAPAR, Cap. 11, p. 121-127.

Martinez, S.S.; Van Emden, H.F.

2001. Growth disruption, abnormalities and mortality of Spodoptera littoralis (Boisduval) (Lepidoptera: Noctuidae) caused by azadirachtin. Neotropical Entomology, 30(1): 113-125.

Medeiros, C.A.M.; Boiça Júnior, A.L.

2005. Efeito da aplicação de extratos aquosos em couve na alimentação de lagartas de Ascia monuste orseis. Bragantia, 64(4): 633-641.

Parra, J.R.P.; Precetti, A.A.C.M.; Kasten Junior, p. 1977. Aspectos biológicos de Spodoptera eridania (Cramer, 1782) (Lepidoptera, Noctuidae) em soja e algodoeiro. Anais da Sociedade Entomológica do Brasil, 6(2): 147-155.

Pereira, J.M.; Seii, A.H.; Oliveira, M.F.; Brustolin, C.; Fernandes, P.M.

2009. Mortalidade de lagartas de Spodoptera eridania (Cramer) pela utilização de Bacillus thuringiensis (Berliner). Pesquisa Agropecuária Tropical, 39(2): 140-143.

Prabhaker, N.; Courdriet, D.L.; Kishaba, A.N.; Meyerdirk, D.E. 1986. Laboratory evaluation of nee-seed extract against larvae of the cabbage looper and beet armyworm (Lepidoptera: Noctuidae). Journal of Economic Entomology, 79: 39-41.
Rodrigues, N.E.L.; Boiça Júnior, A.L.; Faria, P.R.S.

2012. Antibiose e não preferência para oviposição de Bemisia tabaci (Genn.) biótipo B (Hemiptera: Aleyrodidae) por cultivares de Vigna unguiculata (L.) Walp. Arquivos do Instituto Biológico, 79(1): 25-31.

Rosseti, M.R.; Defagó, M.T.; Carpinella, M.C.; Palacios, S.M.; Valladares, G.

2008. Actividad biológica de extratos de Melia azedarach sobre larvas de Spodoptera eridania (Lepidoptera: Noctuidae). Revista de la Sociedad Entomológica Argentina, 67(1-2): 115-125.

Santos, K.B.; Neves, P.J.; Meneguim, A.M.

2005. Biologia de Spodoptera eridania (Cramer) (Lepidoptera: Noctuidae) em diferentes hospedeiros. Neotropical Entomology, 34(6): 903-910.

Santos, J.G.R.; Santos, E.C.X.R. 2008. Agricultura orgânica: teoria e prática. Campina Grande: EDUEPB. 175 p.

Souza, B.H.S.; Boiça Júnior, A.L.; Silva, A.G.; Rodrigues, N.E.L.

2012. Não preferência para alimentação e aspectos biológicos de Spodoptera eridania em cultivares de feijão-caupi. Revista Caatinga, 25(3): 31-37.

Souza, B.H.S.; Costa, E.N.; Silva, A.G.; Boiça Júnior, A.L.

2014a. Aspectos bionômicos de Spodoptera eridania (Cramer): uma praga em expansão na cultura da soja na região do Cerrado brasileiro. Entomobrasilis, 7(2): 75-80.

Souza, B.H.S.; Silva, A.G.; Janini, J.C.; Boiça Júnior, A.L.

2014b. Antibiosis in soybean genotypes and the resistance levels to Spodoptera eridania (Cramer) (Lepidoptera: Noctuidae). Neotropical Entomology, 43(6): 582-587.

Statsoft, Inc. Statistica (data analyses software system), version 7. 2004. Available in: <www.statsoft.com>. Consulted: 02/ $\mathrm{Abr} / 2012$

Thuler, R.T.; Bortoli, S.A.; Goulart, R.M.; Viana, C.L.T.P.; Pratissoli, D.

2008. Interação tritrófica e influência de produtos químicos e vegetais no complexo: Brássicas $\mathrm{x}$ traças-das-crucíferas $\mathrm{x}$ parasitoides de ovos. Ciência e Agrotecnologia, 32(4): 1154-1160.

Torres, A.L.; Barros, R.; Oliveira, J.V.

2001. Efeito de extratos aquosos de plantas no desenvolvimento de Plutella xylostella (L.) (Lepidoptera: Plutellidae). Neotropical Entomology, 30(1): 151-156. 